\title{
KAUM PEDAGANG PEREMPUAN DI PASAR BARU, PELALAWAN, RIAU
}

\author{
Saifullah \\ Dosen Fakultas Ushuluddin UIN Suska Riau
}

\begin{abstract}
This paper is a summary of research conducted in New Market, Pangkalan Kerinci, in referring to the empowerment of women traders in the pattern of ownership (Power of Ownership) on market access, management scheme (Power of Management) and the structuring of the market, as well as making patterns utilization and gains (Power of Utility) more balanced between women traders and merchant men. Empowerment is to reduce direct several factors inherent in a merchant family, poor women are (1) do not have a place to sell permanent (2) the level of buying and selling low, (3) low health, (4) capital is too small, (5) ability to hire los or kiosk, (6) the advantage is not sufficient for basic needs, (7) low wages. Required number of strategic actions in order to empower them, which include short-term actions and long-term action. Programs that need to be done include: $a$. Prioritizing budgets and resources, in order to achieve the goals and objectives of empowerment of poor traders. $b$. Setting priorities and achieving the targets of the merchants perempuan.c empowerment program. Evaluating the achievement of targets and implementation of development programs. $d$. Facilitate market conditions that support through the establishment of local regulations on empowering merchants. $e$. Motivate and strengthen the organization's participation in the empowerment of trader traders women to achieve independence.
\end{abstract}

Keywords: women, traders, Palalawan

\begin{abstract}
Abstrak: Tulisan ini adalah ringkasan penelitian yang dilakukan di Pasar Baru, Pangkalan Kerinci, di maksudkan untuk pemberdayaan kaum pedagang perempuan dalam pola kepemilikan (Power of Ownership) atas akses pasar, pola pengelolaan (Power of Management) dan penataan pasar, serta pola pengambilan pemanfaatan dan keuntungan (Power of Utility) yang lebih seimbang antara pedagang perempuan dan pedagang laki-laki. Pemberdayaan adalah mengurangi secara langsung beberapa faktor yang melekat pada keluarga pedagang perempuan miskin yaitu (1) tidak memiliki tempat berjualan yang tetap, (2) tingkat jual beli yang rendah, (3) kesehatan yang rendah, (4) modal terlalu kecil, (5) kemampuan menyewa los atau kios, (6) keuntungan tidak mencukupi untuk kebutuhan pokok, (7) upah yang rendah. Diperlukan sejumlah aksi strategis dalam rangka pemberdayaan mereka, yang meliputi aksi jangka pendek dan aksi jangka panjang. Program-program yang perlu dilakukan antara lain: a. Memprioritaskan anggaran dan sumber daya, guna mencapai tujuan dan sasaran program pemberdayaan pedagang miskin. $b$. Menetapkan prioritas dan target pencapaian program pemberdayaan kaum pedagang perempuan.c. Mengevaluasi target pencapaian dan pelaksanaan program pemberdayaan. d. Memfasilitasi kondisi pasar yang mendukung melalui penetapan peraturan daerah tentang pemberdayaan pedagang. e. Memotivasi dan menguatkan organisasi partisipasi pedagang dalam pemberdayaan kaum pedagang perempuan untuk mencapai kemandirian.
\end{abstract}

Kata Kunci: Perempuan, Pedagang, Pelalawan

\section{PENDAHULUAN}

Perdagangan pasar sangat identik dengan kaum perempuan, karena memang selain aktivitas berdagang merupakan kegiatan yang easy to enter (mudah dimasuki), yang tidak membutuhkan tingkat pendidikan yang tinggi, juga pekerjaan berdagang merupakan kegiatan yang memerlukan keuletan, kehalusan dan ketelitian yang cocok dilakukan oleh kaum perempuan.

Di kota Pangkalan Kerinci, Kab. Pelalawan terdapat sebuah pasar (Pasar Baru), yang setiap hari menjadi pusat aktivitas jual beli beberapa desa-desa disekitarnya, bahkan penduduk dari desadesa di kecamatan lain yang berdekatan juga 
melakukan transaksi jual beli di pasar ini. Arus total perdagangan mengalir deras, dengan proses jual beli yang terpecah-pecah dan volume perjualan yang relatif berfluktuasi. Melalui observasi awal yang peneliti lakukan dipasar ini, para pedagang perempuan (WomanTraders) belum bisa di kategorikan sebagai suatu kelas pedagang karena belum terdapat perorganisasian diri secara formal.

Kaum pedagang perempuan di Pasar Baru, Pangkalan Kerinci masih sangat memerlukan berbagai tahapan perberdayaan untuk meningkatkan kemampuan dan kemandirian dalam dunia perdagangan, sehingga dapat mengelola pasar dan mengambil keuntungan bersama bagi komunitas pedagang perempuan disana.

Penelitian yang dilakukan di Pasar Baru, Pangkalan Kerinci ini di maksudkan untuk pemberdayaan kaum pedagang perempuan dalam pola kepemilikan (Power of Ownership) atas akses pasar, pola pengelolaan (Power of Management) dan penataan pasar, serta pola pengambilan pemanfaatan dan keuntungan (Power of Utility) yang lebih seimbang antara pedagang perempuan dan pedagang laki-laki.

\section{Urgensi}

Pasar Baru di Pangkalan Kerinci memiliki posisi yang sangat strategis dalam kaitannya dengan perdagangan antar desa dan kecamatan. Pasar ini dipandang sebagai Buffer Zone antara daerah kecamatan dengan desa-desa di sekitarnya. Salah satu aspek pentingnya adalah sebagai pintu gerbang perdagangan di Kab. Pelalawan. Pasar ini berfungsi sebagai distributor barang produk perkotaan ke daerah-daerah di sekitarnya. Kondisi ini menjadikan Pasar ini merangkak sedikit-sedikit berkembang menjadi daerah berdagang yang semakin besar dan mendorong terciptanya berbagai kesempatan kerja, khususnya yang berkaitan dengan sektor perdagangan.

Namun yang sangat disayangkan adalah para pedagang perempuan yang terdiri dari penduduk setempat tidak memiliki akses yang kuat dari segi kepemilikan kios-kios di dalam pasar. Umumnya kios-kios yang ada dikuasai oleh para pedagang laki-laki atau pedagang jarak jauh yang dianggap berjasa menghidupkan pasar ini. Berdasarkan observasi awal yang dilakukan, problema yangterbesar adalah munculnya kekuatan otorisasi pasar dan dominasi pasar yang dilakukan oleh pedagang laki-laki dan pedagang jarak jauh. Mereka adalah pemilik sebahagian besar kios dan sekaligus pedagang yang handal. Para pedagang dari luar kota ini juga ikut dalam pengelolaan dan arus perdagangan di pasar. Oleh karena sistem ini, para pedagang perempuan di kota ini hanya sekedar pelayan toko atau berjualan disebahagian kecil los-los sayuran dan hanya sedikit sekali dapat mengambil keuntungan dari semua transaksi yang berlangsung deras di Pasar Baru. 
Penelitian ini memiliki urgensi yang sangat kuat mengingat ironisme yang dikemukakan diatas yaitu berlangsungnya proses pelemahan pedagang perempuan dan pedagang lokal yang akan berdampak terhadap pola otonomi dan kemandirian pasar-pasar desa di Kab. Pelalawan.

\section{PEMBAHASAN}

\section{Pedagang Perempuan Di Pasar Baru Pangkalan Kerinci, Pelalawan.}

\section{Gambaran Umum Pasar Pelalawan}

Pasar Pelalawan adalah salah satu dari berbagai sistem, institusi, prosedur, hubungan sosial dan infrastruktur dimana usaha menjual barang, jasa dan tenaga kerja untuk orang-orang dengan imbalan uang. Barang dan jasa yang dijual menggunakan alat pembayaran yang sah yaitu uang. Kegiatan berdagang di Pasar ini merupakan bagian dari perekonomian rakyat. Ini adalah pengaturan yang memungkinkan pembeli dan penjual melakukan item pertukaran. Persaingan sangat penting dalam pasar ini, dan memisahkan pasar dari perdagangan. Dua orang mungkin melakukan perdagangan, tetapi dibutuhkan banyak orang untuk memiliki pasar, sehingga ada persaingan pada setidaknya satu dari dua belah pihak. Pertukaran barang atau jasa untuk uang adalah transaksi yang mengalir deras di pasar ini. Peserta Pasar terdiri dari semua pembeli dan penjual yang baik yang memengaruhi harganya. Pasar Pelalawan memfasilitasi perdagangan dan memungkinkan distribusi dan alokasi sumber daya dalam masyarakat. Pasar ini mengizinkan semua item yang diperdagangkan untuk dievaluasi baik harga maupun mutu barang. Menurut sebuah sumber pasar ini muncul lebih atau kurang spontan atau sengaja dibangun oleh interaksi manusia untuk memungkinkan pertukaran hak (kepemilikan) jasa dan barang.

Pasar Tradisional di Pangkalan Kerinci memiliki beberapa fungsi, diantaranya : (1) Fungsi ekonomi, yaitu pasar adalah suatu mekanisme antara membeli dan menjual barang dan jasa pada sebuah harga yang mengarah pada titik keseimbangan. (2) Fungsi sosial, yaitu pasar digunakan sebagai tempat pertemuan sesama kawan, sahabat, berkenalan dengan orang dari tempat lain, bertemu dengan pacar, sebagai pusat informasi dan bahkan untuk mencari pacar. (3) Fungsi budaya, yaitu pasar digunakan sebagai tempat pertunjukan budaya, meskipin tidak dilakukan secara intens. Pertunjukan budaya biasanya hadir dalam bentuk pertunjukan dalam menjual obat-obat tradisional. (4) Fungsi politik, yaitu pasar sebagai pusat keramaian digunakan sebagai wahana untuk memperkenalkan atributatribut kekuasaan individu atau partai tertentu.

Menurut Buku Data Base Pasar Pelalawan ${ }^{1}$ belum ada los-los dalam pasar 
yang rusak. Semua los Pasar baru Pangkalan Kerinci dalam kondisi baik. Pemerintah Daerah membangun 40 unit, dan dibangun secara swadaya oleh masyarakat sebanyak 18 unit. Terdapat juga kantor Pengelola Pasar. Kantor Pengelola Pasar menjadi penting peranannya untuk melakukan pengawasan dan pengelolaan pasar secara berkelanjutan.

Sarana pendukung pasar menjadi sangat penting untuk menunjang kenyamanan para konsumen yang berbelanja atau melakukan transaksi di pasar. Pengelolaan pasar yang diindentifikasi dalam penelitian ini adalah pengelompokan pedagang dalam satu kawasan atau area tetentu untuk setiap jenis karakteristik komoditi yang dijual, atau lebih dikenal dengan istilah zooning pedagang. Zooning pedagang menjadi sangat penting untuk mengelompokkan pedagang yang sejenis karakteristik komoditinya kedalam satu blok tertentu, sehingga memudahkan pembeli untuk berbelanja kebutuhan-kebutuhannya. Zooning juga berperan untuk menjaga kebersihan pasar dan menjaga produk yang dijual, khususnya pada para pedagang makanan yang menuntut higienitas (kebersihan) dan kenyamanan pembeli saat menikmati produk makanan yang dinikmati dikawasan pasar.

\section{Profil Pedagang Perempuan}

Para pedagang perempuan, terbagi ke dalam empat golongan pedagang, yaitu pertama, sekelompok kecil pedagang sandang mewah yang menjual kain batik, tenun dan tekstil serta emas. kedua, segolongan pedagang perempuan desa semiprofesional atau pedagang pasar dengan skala yang kecil sekali, diantaranya banyak wanita yang hampir secara menyeluruh berdagang di semua lokasi pasar (termasuk kaki lima). Ketiga, segolongan pedagang yang sepenuhnya profesional dan yang semula pedagang keliling yang menjual barang-barang kebutuhan sehari-hari. keempat, pedagang perempuan yang menjual berbagai barang kebutuhan, bahkan barang impor. Sebagian besar pedagang kecil adalah wanita, yang berasal dari istri petani, istri perajin sambilan kecil atau istri pemilik home industri, mereka berurusan dalam kerajinan tangan yang dihasilkan.

Pedagang perempuan memilih usaha dagang kecil-kecilan lewat los-los, kios, dan kaki lima. Pilihan pola dagang ini terjadi disebabkan jenis dan tipe dagangan ini mudah untuk dimasuki dan tidak memerlukan modal yang besar.

\section{Tipe pedagang perempuan berdasarkan}

\section{temuan}

Pedagang perempuan yang beroperasi di pasar Pasar Baru Pangkalan Kerinci dapat diuraikan sebagai berikut:

1. Pedagang pasar adalah kelompok pedagang perempuan yang melakukan kegiatan berjualan di dalam pasar. Mereka menggelarkan barang jualannya pada sebuah ruangan terbuka berbentuk 
los yang di beri lantai semen. Jenis komoditi yang diperjualkan adalah berupa barang-barang kebutuhan seharihari seperti bumbu-bumbuan, sayursayuran, buah-buhan lokal dan sebagainya. Pedagang ini bisa mengambil tempat di los atau bersifat lesehan.

2. Pedagang warung adalah satu dari tipe pedagang perempuan yang aktivitasnya menjual barang-barang kebutuhan harian. Lokasinya di sebelah luar dari pasar sehingga masyarakat luas bisa berbelanja kepada mereka. Pedagang warung juga ada disetiap jalan disekitar rumah-rumah penduduk. Bagi masyarakat pedagang warung memiliki peranan cukup besar bagi menyediakan kebutuhan sehari-hari masyarakat sekitar.

3. Pedagang kios merupakan salah-satu pelengkap aktivitas pasar yang terklasifikasi sesuai dengan komoditi yang dijual di dalam pasar. Mereka mendapatkan barang dari Kampas (pedagang yang menyalurkan dari grosir) dan menjualnya kembali kepada konsumen secara eceran atau pedagang lain yang lebih kecil.

4. Pedagang toko, merupakan kelompok pedagang perempuan yang mempunyai aktivitas tetap disebuah tempat yang permanen, hanya perbedaannya pedagang toko mempunyai skala usaha yang lebih besar dari pada pedagang warung. Komoditi yang diperjualkan meliputi barang-barang kelontong dan berbagai barang-barang kebutuhan sehari-hari. Lokasi pedangan toko berada di sekitar gerbang pasar.

Grosir, merupakan tipe pedagang yang membeli barang dagangan dalam jumlah besar dan langsung dari produsen. Mereka memasarkan dagangannya melalui para pedagang kecil. Gosir lebih disukai oleh konsumen, karena harga yang mereka patok jauh lebih murah dibandingkan dengan pedagang lain. Namun tidak semua grosir bersedia menjual barang secara eceran. Pedagang perempuan sedikit sekali jumlahnya yang menjadi grosir.

Di pasar Pasar Baru Pangkalan Kerinci terdapat grosir ikan (ikan laut, ikan sungai dan ikan salai), gula, pecah belah dan lain-lain.

Terdapat tipe-tipe pedagang perempuan yang tidak bisa dianggap berorientasi hanya mencari untung dan membesarkan skala usaha mereka, tetapi merupakan pedagang kecil yang hanya mencari sedikit keuntungan untuk memenuhi kebutuhan sehari-hari mereka. Mereka diistilah dengan survival traders, strategi yang digunakan adalah strategi memenuhi kebutuhan pokok dan memiliki karakter yang enggan terhadap resiko kerugian, enggan terhadap kredit, perluasan usaha atau yang penting selamatkan kebutuhan rumah tangga dahulu melalui kelanggengan usaha dagangannya. Pedagang 
tipe ini merupakan perdagangan dengan skala usaha kecil-kecilan, tidak memerlukan keterampilan tinggi dan oleh karena sifatnya yang mudah dimasuki (easy toenter). Para warga desa sangat senang dengan tipe ini, yang mereka anggap sebagai alternatif untuk mencari tambahan pendapatan selain dari bertani dan berkebun.

\section{Jenis Dagangan}

Jenis komoditi yang diperjual-belikan pedagang perempuan menentukan tipe kios dan penempatan para pedagang sesuai dengan klasifikasi dagangan.

1. Tipe A ditempati oleh pedagang emas, toko jam, toko obat dan kosmetik.

2. Tipe B ditempati oleh pedagang makanan dan minuman ringan, grosir dan eceran serta sembako komplit.

3. Tipe $\mathrm{C}$ ditempati pedagang kain, pakaian jadi, serta sepatu dan tas.

4. Tipe D ditempati pedagang pecah belah, kelontong dan alat-alat kampong.

5. Tipe E ditempati pedagang yang menjual alat-alat tulis, kaset dan aksesoris.

6. Tipe $F$ ditempati pedagang pakaian bekas, tukang jahit/obras serta alat-alat jahit.

7. Tipe $\mathrm{G}$ ditempati pedagang makanan dan minuman ( warung nasi Ampera, lontong, soto dan kedai kopi)

Sedangkan kios tambahan ditempati oleh pedagang kelapa, kantong plastik, bahanbahan bumbu basah seperti cabe, bawang, kol dan sayuran, yang umumnya didominasi oleh pedagang perempuan.Sementara itu pedagang perempuan yang menempati loslos di pasar Pasar Baru Pangkalan Kerinci terdiri dari pedagang yang dapat diklasifikasikan menurut jenis komoditi yang diperjual-belikan. Disediakan dalam fasilitas yang memadai untuk los ayam, los ikan dan los daging.Los-los di pasar Pasar Baru Pangkalan Kerinci merupakan bangunan semi permanen yang telah dibuat sedemikian rupa dalam bentuk lapang dan terbuka dengan deretan meja-meja yang terbuat coran semen dan pasir. Khusus untuk los daging, ikan dan ayam dibuat dengan memakai keramik. Masing-masing meja beukuran 1 X $2 \mathrm{M}$.

Selain itu yang berjualan di los terbuka juga banyak, menurut catatan penulis terdapat kurang lebih 90-an orang yang menggelar dagangannya secara terbuka dipinggirpinggir pasar beralaskan papan yang dibuat seperti lantai. Di tempat seadanya ini dan tanpa dipayungi atap mereka berjualan sayur-sayuran, tahu/tempe, ayam, ikan air tawar dan lain-lain.

\section{Dinamika Pedagang Perempuan Pasar Baru}

Penunggu kedai-kedai kain di Pasar Baru pada umumnya perempuan. Mereka adalah orang-orang yang tidak memiliki modal untuk mendirikan toko kain dan baju, membangun atau menyewa toko dan isinya. Bentuk kepemilikan toko baju-baju dan kainmerupakan usaha perseorangan ataupun persekutuan. Jika bentuk persekutuan maka 
pembagian hasil usaha ( laba) dapat dibagi rata dalam bentuk jumlah uang, atau dengan cara pembagian waktu operasional kedai. Di Pasar Baru, pemilik modal selalu berusaha mengembangkan usaha, dari mulai satu toko kain sampai dengan beberapa toko yang didirikannya, Tidak ada sebutan khusus untuk pemilik modal, pekerja memanggil pemilik modal dengan sebutan kekerabatannya saja.

Pedagang perempuanpenunggu kedai-kedai dan toko-toko kain adalah mereka yang ikut bekerja pada pemilik modal dan yang diajak atau dipekerjakan oleh pemilik modal, dan biasanya mereka adalah saudara atau tetangga dari pemilik modal, serta pekerja lain. Akan tetapi bentuk kesepakatan dari pemilik modal dengan pekerjanya tersebut berbeda-beda. Kesepakatan awal antara pemilik modal dengan saudara (pekerja) pemberian upah dilakukan dengan sistem bagi hasil dan tidak ada tuntutan-tuntutan atau target penjualan dari pemilik modal, serta memiliki hak kendali terhadap operasional toko atau kedai. Hubungan antara pemilik modal ( induk semang) dan pekerja (pedagang perempuan) juga berlangsung di Pasar Baru Pangkalan Kerinci, hubungan ini berlangsung sebagai suatu keadaan khusus dari persekutuan dyadic (dua orang) yang melibatkan sebagian besar persahabatan, sementara seorang atau kelompok yang berstatus sosial ekonomi lebih tinggi berperan sebagai induk semang, menggunakan pengaruh, dan penghasilannya untuk memberikan perlindungan dan kebaikan kepada seseorang atau kelompok yang memiliki status sosial ekonomi lebih rendah. Kelompok ini berperan sebagai anak buah (yang umumnya adalah perempuan), bersedia membalas budi berupa dukungan menyeluruh yang meliputi seluruh pekerjaan yang disuruh induk semang.

Selanjutnya, ciri hubungan induk semang dan pekerja berbeda dengan hubungan sosial lain. Ciri pertama: adanya ketidakseimbangan (inequality) dalam pertukaran. Ketidakseimbangan terjadi karena induk semang berada dalam posisi pemberi barang atau jasa yang sangat diperlukan bagi pedagang perempuan penunggu kedai/toko dan keluarganya agar mereka dapat tetap hidup. Rasa wajib membalas pada diri pedagang perempuan muncul akibat pemberian tersebut, selama pemberian itu masih mampu memenuhi kebutuhan yang paling pokok. Jika pedagang perempan merasa apa yang dia berikan tidak dibalas sepantasnya oleh patron, dia akan melepaskan diri dari hubungan tersebut tanpa sangsi. Dalam hubungan induk semang dan para pekerjanya juga harus didukung oleh norma-norma masyarakat yang memungkinkan pihak yang lebih rendah kedudukannya (pedagang perempuan) melakukan penawaran, artinya jika salah satu pihak merasa bahwa pihak lain tidak memberi seperti yang diharapkan, 
dia dapat menarik diri dari hubungan itu tanpa sangsi. Ciri kedua: adalah sifat tatap muka. Sifat ini memberi makna bahwa hubungan induk semang dan pedagang perempuan adalah hubungan personal, yaitu hubungan yang didasari rasa saling percaya. Masing-masing pihak mengandalkan penuh pada kepercayaan, karena hubungan ini tidak disertai perjanjian tertulis. Dengan demikian, walaupun hubungan induk semang dan pedagang perempuan bersifat instrumental, artinya kedua belah pihak memperhitungkan untung-rugi, namun unsur rasa dan norma selalu menyertai.

Ciri ketiga adalah sifatnya luwes dan meluas. Dalam relasi ini bantuan yang diminta induk semang dapat bermacam-macam, mulai membantu membersihkan rumah, mengantar anak sekolah, sampai menyetor uang ke bank. Pekerja mendapat bantuan tidak hanya pada saat mengalami musibah, tetapi juga bila mengalami kesulitan mengurus sesuatu. Hubungan induk semang dan pedagang perempuannya di Pasar Baru Pangkalan Kerinci selalu menempatkan perempuan sebagai pekerja, sebagai suatu keadaan khusus dari persekutuan dyadic yang melibatkan sebagian besar persahabatan, sementara seorang atau kelompok yang berstatus sosial ekonomi lebih tinggi berperan sebagai induk semang, induk semang umumnya didominasi oleh kaum laki-laki, yang menggunakan pengaruh, dan penghasilannya untuk memberikan perlindungan dan kebaikan kepada seseorang atau kelompok yang memiliki status sosial ekonomi lebih rendah. Kelompok perempuan berperan sebagai penunggu toko/kedai, bersedia membalas budi berupa sifat rajin dan prilaku baik kepada induk semang. pandangan tersebut memberi petunjuk bagi yang memiliki atau menguasai sumber daya yang diperlukan dalam masyarakat dan hubungan induk semang dan bawahannya berlangsung, sebaliknya bagi yang tidak menguasai sumber daya langka berada pada posisi pekerja.

Pada kalangan pedagang toko kain, yang dipandang sebagai induk semang adalah pemilik modal yang umumnya laki-laki. Peranan pemilik modal tidak hanya sebatas menyediakan toko dan isinya, namun juga menyediakan bahan fasilitas kedai, menyewa toko, menyediakan perlengkapan berjualan, mencarikan lokasi usaha untuk berdagang, dan menyediakan rumah tempat tinggal, serta memenuhi kebutuhan vital pegawai perempuannya. Kebutuhan vital ini adalah seperti kebutuhan makan sehari-hari, menyediakan kamar tidur, dan kamar mandi yang tidak terdapat dalam tokonya. Sumber daya secara nyata yang dimiliki pemilik modal dapat dilihat dari kekuatan pemilik modal untuk mendirikan toko empat sampai delapan toko atau menampung delapan sampai lima belas pedagang perempuan.

Faktor lain yang menjadikan pedagang perempuan bertahan dalam hubungan induk semang dan bawahannya adalah risiko 
kegagalan usaha, seperti jatuh bangkrut, keuntungan tidak memadai, kesulitan mendapatkan lokasi jualan yang strategis, karena itu umumnya pedagang perempuan tidak mau mandiri. Dengan demikian, apa yang semula diperhitungkan bahwa terjadi ketidakseimbangan keuntungan, ternyata bagi pihak-pihak yang terlibat dalam pola hubungan itu mempunyai penilaian sendirisendiri terhadap nilai barang yang mereka pertukarkan, semakin dibutuhkan barang atau jasa maka semakin tinggi pula nilai barang itu baginya. Bagi Pemilik modal, kesetiaan, kejujuran, serta tenaga kerja yang dimiliki pedagang perempuan sebagai bawahannya mempunyai nilai yang tinggi.

Terjadinya hubungan induk semang dan anak buah pada pedagang perempuan merupakan bagian dari berkembangnya hubungan kekerabatan berjualan di kawasan Pelalawan, disebabkan oleh (1) Adanya ketimpangan mencolok dalam penguasaan atas kekayaan, status dan kekuasaan, mengingat hal ini sedikit banyak dianggap sah oleh mereka yang terlibat di dalamnya; (2) Tidak adanya pranata yang menjamin keamanan individu, baik yang menyangkut status maupun kekayaan; (3) Tidak dapat diandalkannya ikatan kekerabatan saja sebagai sarana satu-satunya mencari perlindungan serta memajukan diri. Kondisikondisi yang dikemukakan tersebut memang hadir di kalangan pedagang perempuan di Pasar Baru Pangkalan Kerinci.
Ketidakamanan fisik dan sosial adalah kondisi lain yang juga mendukung kehadiran hubungan induk semang dan bawahan adalah ketidakamanan fisik dan sosial di tengah kelangkaan komoditi penting yang diperlukan. Jalan terbaik bagi mereka adalah menempel atau bergantung kepada seseorang yang lebih berkuasa, yang lebih mampu melindungi atau memberi mereka segala sesuatu yang diperlukan. Begitu juga kondisi yang dialami pedagang perempuan di Pasar Baru. Suasana tidak aman baik fisik ataupun sosial akan dirasakan apabila kedatangan mereka tanpa bantuan kenalan, saudara, sahabat yang bersedia memberi jaminan fisik ataupun sosial. Hubungan induk semang dan anak buahnya yang umumnya adalah perempuan, pedagang penunggu toko-toko, kedai-kedai, kios dan los-los merupakan salah satu bentuk hubungan pertukaran khusus antara dua pihak, yakni antara mereka yang mempunyai status, kekayaan dan kekuatan lebih tinggi (pemilik modal)dengan mereka yang memiliki status dan kekayaan lebih rendah (pedagang perempuan). Terjadinya hubungan tersebut dikarenakan kepemilikan sumber daya usaha, unit kekerabatan, dan kebutuhan ekonomi sehari-hari.

\section{Masalah Pedagang Perempuan}

Pokok masalah adalah faktor penyebab kekalahan pedagang perempuan yang dinilai mendesak dan penting untuk segera ditangani Pemerintah Daerah 
Pelalawan. Pokok masalah yang dipaparkan di bawah ini sudah barang tentu bukan masalah orang per-orang atau yang sifatnya kasuistis saja, tetapi masalah di tingkat komunitas atau kelembagaan yang menyangkut hajat hidup orang banyak.

Secara rinci, pokok masalah pemberdayaan kaum pedagang perempuan yang berhasil diidentifikasi dari proses perencanaan yang sifatnya bottom-up (dari bawah) adalah sebagai berikut:

Pertama, tidak dimilikinya asset modal berjualan yang memadai dan kurangnya kemampuan pedagang perempuan dalam upaya pengembangan kegiatan produktif dalam berniaga dan kegiatan deversifikasi usaha. Di Pelalawan, kelompok pedagang perempuan yang diperkirakan paling terpukul adalah mereka yang termasuk kelompok masyarakat yang tidak stabil, mudah tergeser, rapuh, miskin, dam rendah tingkat pendidikannya

Para pedagang perempuan disinyalir memiliki tingkat ketergantungan yang tinggi terhadap pihak yang lebih kuat dan memiliki posisi tawar yang rendah terhadap kelas sosial di atasnya. Diketahui pula bahwa umumnya para pedagang perempuan buta hukum, jauh dari akses pelayanan publik, terisolasi dari informasi dan koneksi, tidak memiliki induk semang yang kuat, sehingga sangat tergantung pada sedikit sumber penghasilan tertentu. Akibat dari situasi ini, pedagang perempuan sebagian besarnya jarang yang mampu berdiri sendiri karena kelemahan-kelemahan yang disebutkan.

Kedua,rendahnya akses pedagang perempuan terhadap berbagai fasilitas pelayanan modal dan akses terhadap penyewaan kedai-kedai, kios dan toko. Hanya induk semang mereka yang mengerti dengan prosedure penyewaan toko, kios dan los yaang dilakukan kontraknya bersama Pemda Pelalawan. Disadari bahwa salah satu masalah yang timbul di Kecamatan Pelalawan adalah upaya penyediaan dan kemampuan pemerintah itu untuk memberikan layanan dan fasilitas publik secara memadai. Bukan rahasia lagi, bahwa bagi pemerintah Kecamatan Pelalawan ternyata di saat yang sama harus berhadapan dengan masalah keterbatasan dana untuk membangun fasilitas pasaryang memadai. Kalau pun jumlah los, kios dan toko yang tersedia mencukupi, tetapi akibat rendahnya akses pedagang perempuan terhadap berbagai prosedur pelayanan fasilitas ini, maka yang terjadi kemudian adalah disparitas antara kebutuhan dan keterbatasan kemampuan.

\section{Strategi Pemberdayaan Pedagang Perempuan di Pasar Baru Kerinci}

Panduan umum pemberdayaan pedagang perempuan yang disarankan untuk dikembangkan di Kecamatan Pelalawan adalah : Pertama, memperjelas kelompok sasaran program pemberdayaan pedagang perempuan. Dengan mempertajam 
sasaran kelompok ini, maka yang diharapkan adalah upaya-upaya pengentasan pedagang perempuan atau program pembangunan pasar tradisional secara umum yang benarbenar dapat terarah, dan menjangkau lapisan pedagang perempuan yang berada di lapisan paling bawah. Bila kelompok sasaran tidak terarah biasanya program akan rawan bias, dan tidak mustahil jatuh kepada orang-orang yang sebenarnya tidak berhak.

Kedua, mendorong pemberdayaan dan pengembangan kegiatan produktif pedagang miskin, khususnya perempuan. Selama ini, kekurangan pokok yang perlu diperhatikan dari berbagai upaya pengentasan masyarakat miskin adalah bahwa mereka menjadi begitu memusatkan perhatian pada peningkatan kuantitas produksi atau hasil kegiatan produktif pedagang miskin, sehingga kebutuhan sistem produksi mendapat tempat yang lebih utama daripada kebutuhan masyarakat miskin yang lebih substansial.

Ketiga, meningkatkan posisi bargaining (tawar) dan mengurangi kerentanan pedagang perempuan. Artinya, program pembangunan sosial dan upaya penanggulangan kemiskinan seyogianya tidak hanya terjebak pada program yang sifatnya karitatif dan apalagi yang bersifat punitif, melainkan harus lebih mengedepankan program yang berorientasi pada proses pemberdayaan, yang intinya bersifat people centered, participatory, empowering, dan sustainable.
Keempat, meningkatkan peran lembaga lokal dan kelompok sekunder di masyarakat dalam upaya monitoring dan pelaksanaan program pemberdayaan pedagang perempuan. Agar pelaksanaan program pemberdayaan pedagang perempuan tidak mengalami penyimpangan atau bias di tingkat pelaksanaan, maka prasyarat yang dibutuhkan selain harus ada jaminan bahwa proses pelaksanaan program berjalan secara transparan, yang tak kalah penting adalah harus didukung oleh mekanisme dan sistem kontrol yang kuat, khususnya pelibatan dan kontrol dari organisasi pedagang perempuan itu sendiri sebagai kelompok sasaran dan kontrol dari lembaga-lembaga lokal dan kelompok sekunder di masyarakat.

\section{Program Utama}

Program utama pemberdayaan pedagang perempuan adalah sebagai panduan yang memberi arah kebijakan strategis pemberdayaan pedagang perempuan, untuk sektoral, lokal dan regional dalam jangka pendek, menengah, dan panjang bagi Pemda Pelalawan

Seperti telah diuraikan sebelumnya bahwa kemiskinan dikalangan pedagang perempuan bersifat multidimensi yaitu sebagai kondisi dimana perempuan tidak dapat memenuhi hak-hak dasarnya untuk mempertahankan dan mengembangkan kehidupan yang bermartabat. Tanpa 
mengurangi makna multidimensi dari kekalahan kaum pedagang perempuan, maka program pemberdayaannya dibagi atas dua bagian yaitu program jangka pendek dan jangka panjang. Program jangka pendek lebih banyak dipandang dari dimensi yang lebih terbatas, yaitu dari dimensi ekonomi, sedangkan program jangka panjang adalah untuk dimensi yang lebih luas (multidimensi) yang meliputi aspek kesehatan, pendidikan dan kebudayaan (sumber daya manusia) dan dimensi infrastruktur. Hal ini dimaksudkan agar perumusan program penanggulangan kemiskinan oleh Satker terkait Iebih mudah dan fokus, tidak tumpang tindih. Berdasarkan kajian data sekunder dan literatur yang ada tentang akar masalah maka strategi utama pemberdayaan dibagi menjadi 4 (empat) panduan utama yaitu:

1. Perluasan kesempatan, yaitu strategi pemberdayaan dengan penciptaan kondisi dan lingkungan pasar, ekonomi, politik, dan sosial yang memungkinkan pedagang miskin memperoleh kesempatan seluasluasnya dalam pemenuhan hak-hak dasar dan peningkatan taraf hidup secara berkelanjutan,

2. Pengentasan pedagang perempuan, yaitu program pemberdayaan dengan melakukan penguatan kelembagaan sosial, politik, ekonomi, dan budaya masyarakat bernafaskan jender, dan memperluas partisipasi pedagang perempuan dalam pengambilan keputusan kebijakan publik,

Disamping perlunya memperhatikan isu lintas bidang (crosscutting issues) yaitu mengutamakan jender (gender mainstream), tata-pemerintahan (governance), isu lingkungan, dan desentralisasi.

\section{Program Pemberdayaan Pedagang}

\section{Perempuan}

Kebijakan pemberdayaan kaum pedagang perempuan adalah kebijakan publik yang harus berpihak kepada pedagang perempuan miskin (pro-poorpolicy), sehingga harus diterjemahkan sebagai kebijakan pembangunan yang berpihak kepada orang miskin (pro-poor-development) dan pertumbuhan (ekonomi) yang berpihak kepada orang miskin (Pro-poor-growth).

$$
\text { Kebijakan pembangunan harus }
$$
diarahkan pada: (1) sektor dan kawasan pasar yang mampu tumbuh dan menciptakan lapangan kerja yang tinggi; (2) sektor-sektor dan kawasan dengan konsentrasi pedagang miskin yang tinggi; (3) kegiatan-kegiatan yang memungkinkan pedagang perempuan keluar dari perangkap kemiskinan secara berkelanjutan; dan (4) kegiatan yang dapat mengurangi pembiayaan kehidupan pedagang miskin secara berarti sehinga beban hidupnya berkurang. Dengan demikian, kebijakan dan program pemberdayaan tersebut akhirnya memberi dampak nyata pada pencapaian 
hasil untuk mengurangi jumlah pedagang miskin di Kab. Pelalawan.

Dalam program infrastruktur penekanannya adalah pada program pembangunan infrastruktur di Pasar Baru yang terkait langsung dengan pedagang miskin, misalnya pembangunan kios dan auning serta los yang sewanya murah, jalan masuk dan keluar pasar yang baik. Secara konkrit program pemberdayaan tersebut dapat dijabarkan lebih lanjut dalam bentuk; Pertama, program jangka pendek yang menyentuh dan berdampak langsung terhadap kehidupan pedagang perempuan. Kedua, adalah program jangka menengah dan panjang yang memerlukan waktu untuk menimbulkan dampak nyata terhadap kehidupan pedagang perempuan tetapi program ini secara substansial sangat penting karena program ini terkait langsung dengan akar masalah dan penyebab kekalahan mereka. Program pertama lebih banyak bersifat penyelamatan (rescue) yang menghilangkan gejala-gejala yang timbul akibat kemiskinan. Dengan kata lain program ini adalah program yang bersifat quick fix.

Program kedua bersifat jangka menengah atau panjang karena dampaknya baru dirasakan masyarakat dalam waktu yang relatif lama, misalnya program pembukaan pasar yang baru untuk mengatasi pengangguran tidak bisa memberikan hasil yang cepat karena memerlukan investasi, iklim usaha yang kondusif, kebijakan pemerintah yang pro bisnis, dan lain sebagainya. Walaupun program ini bersifat jangka panjang namun sangat diperlukan karena program ini langsung menyentuh akar dan penyebab dari kemiskinan, yaitu pengangguran.

\section{Aksi Pemberdayaan Pedagang Perempuan}

Sesuai dengan tujuan program pemberdayaan maka program jangka pendek dan panjang dibedakan dari lamanya suatu program dapat memberikan dampak terhadap pedagang perempuan. Jangka pendek adalah waktu yang diperlukan oleh suatu program aksi untuk dapat menghilangkan gejala kelemahan mereka Program jangka pendek ini berlangsung selama program jangka panjang (misalnya, pembangunan los dan kios yang baru, membangun pasar yang baru, penataan organisasi pedagang, penciptaan lapangan kerja tambahan bagi keluarga pedagang perempuan) belum mampu meningkatkan pendapatan pedagang perempuan, atau sampai ada program alternatif yang lebih baik. Dengan kondisi ekonomi dan keaadaan pasar baru yang ada sekarang ini maka jangka program jangka pendek pendek diperkirakan adalah 2 sampai 3 tahun.

Berdasarkan uraian diatas maka sasaran Rencana Aksi jangka pendek pemberdayaan adalah mengurangi secara langsung beberapa faktor yang melekat pada keluarga pedagang miskin yaitu (1) tidak memiliki tempat berjualan yang tetap, (2) tingkat jual beli yang rendah, (3) kesehatan 
yang rendah, (4) modal terlalu kecil, (5) kemampuan menyewa los atau kios, (6) keuntungan tidak mencukupi untuk kebutuhan pokok, (7) upah yang rendah, dan lain-lain. Pedagang dikatakan miskin apabila variabel tersebut terpenuhi. Namun Rencana Aksi jangka pendek ini tidak menyelesaikan masalah dalam jangka panjang karena akar permasalahan belum disentuh oleh program ini. Misalnya, dengan memberikan beras untuk orang pedagang miskin (Raskin) hanya dapat mengatasi masalah kekurangan makan dan protein dalam jangka pendek sehingga tidak jatuh korban kelaparan dan gizi buruk. Dalam Rencana Aksi jangka menengah dan panjang fokus program adalah pada bidang ekonomi yang akan menimbulkan dampak nyata dan permanen dalam jangka panjang. Disamping itu program di bidang sarana berjualan dan permodalan juga perlu diperhatikan karena kedua program ini sangat erat kaitannya dengan bidang ekonomi. Sasaran dari rencana aksi jangka menengah dan panjang ini adalah untuk mengatasi akar permasalahan atau penyebab timbulnya ketakberdayaan. Misalnya, kenapa pedagang miskin tersebut tidak mampu memenuhi kebutuhan hariannya, tidak bisa mempunyai rumah yang layak, dan tidak bisa akses terhadap rumah sakit, dan seterusnya.

\section{Rencana Aksi Pemberdayaan Pedagang Perempuan}

Berikut ini diberikan penjelasan ringkas untuk beberapa program untuk menghindari interpretasi yang mungkin berbeda.

\section{Rencana Aksi Jangka Pendek}

1. Permasalahan utama pada para pedagang adalah masalah permodalan untuk berniaga berbunga rendah, seringkali distribusi yang tidak lancar dan tidak tepat sasaran. Untuk itu kualitas distribusi bantuan modal perlu diperbaiki sehingga dicapai bantuan modal yang tepat, yaitu tepat penerima, tepat waktu, tepat tempatnya, tepat harga dan tepat nominalnya. Ini untuk menghindari praktek pinjaman modal dari rentenir yang mencekik para pedagang perempuan

2. Perlunya pelatihan untuk para pedagang perempuan meningkatkan kemampuan berniaga. Mereka harus mengerti dimana harus membeli barang dagangan yang murah sehingga dapat keuntungan yang lebih baik, juga skil dan pengetahuan untuk meminjam ke Bank yang menyediakan kredit ringan berbunga rendah untuk pedagang kecil.

3. Perlunya dibangun segera kios dan los serta auning tambahan untuk pedagang PKL dan pedagang yang berniaga di jalan masuk dan keluar pasar. Pemberian kios, los adalah lebih bersifat perlindungan sosial dibandingkan nilai ekonomis bagi Pemda. Kios dan los dibangun khusus 
untuk pedagang miskin yang tidak mampu menyewa los dan kios yang ada.

\section{Program Jangka Panjang}

\section{A. Bidang Ekonomi}

1. Pada tingkat perencanaan perlu dibentuk Tim Khusus Pemberdayaan kaum Pedagang kecil yang berfungsi mengkoordinasikan perencanaan pembangunan antar pasar di tingkat kecamatan. Perencanaan yang baik adalah dalam pembuatan perencanan tersebut perlu melibatkan ahli perencanaan yang mendengarkan aspirasi masyarakat bawah. Untuk ini diperlukan tenaga pendamping profesional dan penguatan lembaga dan organisasi kaum pedagang lainnya yang akan membantu pemerintah daerah dalam perumusan, implementasi dan pengawasan pelaksanaan pembangunan.

2. Mendorong Pemerintah kab. Pelalawan agar memberi kewenangan kepada Dinas pasar Pelalawan untuk merencanakan, memutuskan dan melaksanakan program pemberdayaan pedagang di seluruh pasar di Pelalawan.

3. Salah satu kendala dalam mengembangkan usaha dagang dipasar tradisonal adalah terbatasnya modal. Untuk itu pembangunan lembaga keuangan mikro perlu didekatkan ke pasar-pasar tradisional. Bila pedagang kecil tidak sanggup membayar bunga pinjaman maka pemerintah perlu memberikan subsidi bunga.

Bagi pedagang perempuan yang masih produktif perlu pembinaan yang intensif dan pelatihan untuk meningkatkan ketrampilan berniaga sehingga bisa mandiri. Para pedagang perempuan penunggu toko diharapkan dapat memiliki kios atau los untuk berniaga secara mandiri bukan sebagai anak buah yang bisa diexploitasi oleh induk semangnya.

\section{B. Bidang Sumber Daya Manusia}

Kebijakan di bidang skill dan pendidikan adalah peningkatan pelayanan penyuluhan dan pelatihan bagi pedagang perempuan. Kebijakan yang perlu mendapat penjelasan antara lain, pengembangan skill berbasis potensi lokal, yakni pelatihan yang dikembangkan sesuai dengan potensi daerah yang bisa dikembangkan sehingga memberikan nilai tambah lebih besar di daerah tersebut dan menciptakan lapangan pekerjaan khususnya di pasar bagi penduduk setempat.

\section{Bidang Infrastruktur}

1. Program kios dan los swadaya bukan bersifat perlindungan tetapi adalah program yang ditujukan bagi pedagang miskin yang masih produktif, artinya masih bisa bekerja tetapi tidak mampu untuk memenuhi kebutuhannya sehingga tergolong miskin. Untuk 
mereka ini disediakan pembangunan kios dan los secara swadaya, misalnya dengan pemberian stimulan berupa bahan bangunan, kredit ringan, dana bergulir dan lain-lain. Selanjutnya mereka sendiri yang meneruskan pembangunan kios dan los tersebut secara swadaya.

2. Pembangunan tempat pembuangan sampah dan drainase serta instalasi pengolahan air bersih tepat guna dan sederhana yang bisa dioperasikan dan dirawat sendiri oleh para pedagang pasar tanpa harus membelit mereka dengan sistem restribusi yang mahal.

3. Perlu disegerakan pembangunan jalan yang permanen untuk masuk dan keluar pasar, serta jalan dilingkungan pasar yang layak dan becek di musim hujan.

\section{KESIMPULAN DAN SARAN}

Pasar baru Pelalawan merupakan pasar tradisonal yang memiliki keunggulan bersaing alamiah yang tidak dimiliki secara langsung oleh pasar modern. Lokasi yang strategis, area penjualan yang luas, keragaman barang yang lengkap, harga yang rendah, sistem tawar menawar yang menunjukkan keakraban antara penjual dan pembeli merupakan keunggulan yang dimiliki oleh pasar tradisional ini.

Namun, selain menyandang keunggulan alamiah, pasar tradisional ini memiliki berbagai kelemahan yang telah menjadi karakter dasar yang sangat sulit diubah. Faktor desain dan tampilan pasar, atmosfir, tata ruang, tata letak, keragaman dan kualitas barang, promosi penjualan, jam operasional pasar yang terbatas, serta optimalisasi pemanfaatan ruang jual merupakan kelemahan terbesar pasar tradisional yang harus dibenahi. Ketika konsumen menuntut 'nilai lebih' atas setiap uang yang dibelanjakannya, maka kondisi pasar pasar tradisional yang kumuh, kotor, bau, dengan atmosfir seadanya dalam jam operasional yang relatif terbatas tidak mampu mengakomodasi hal ini.Belum lagi kenyataan, bahwa mayoritas konsumen berasal dari kalangan menengah ke bawah.Kondisi ini menjadikan konsumen pasar tradisonal tergolong ke dalam konsumen yang sangat sensitif terhadap harga.

Beberapa kelemahan harus diatasi oleh para pedagang perempuan jika ingin bersaing dengan pedagang luar yang secara permanen telah lama menguasai arus jual beli di pasar ini. Keterampilan berniaga, kepiawaian dan kegigihan serta akses kepada informasi perdagangan dan harga pasaran barang-barang semasa harus diatasi untuk dapat mengentaskan para pedagang lokal, jika mereka ingin mengambil keuntungan bersama dalam arus jual beli yang berlangsung di pasar mereka.

Berdasarkan pembahasan, maka disarankan agar Dinas Pasar kabupaten Pelalawan harus memberi perhatian yang 
khusus terhadap pemberdayaan pedagang perempuan di Pasar Baru. Mereka harus di beri pelatihan untuk bisa bersaing secara sehat dengan pedagang pria. Pedagang perempuan harus diberi akses kepada bantuan kredit dan pembentukan organisasi yang kuat, serta informasi yang cepat tentang situasi dan seluk beluk perdagangan untuk memberdayakan mereka dari segi modal dan keterampilan berniaga.

1 PT Kuantan Graha Marga, Data Base Pasar Kabupaten Pelalawan, Dinas Perindustrian Perdagangan dan Pasar Kabupaten Pelalawan, 2012, hal. 37

\section{DAFTAR PUSTAKA}

Astuti, Sri Puji dan Suyanto, Muzakka, Keprianto, Catur (2004) Prospek Sektor Informal Perdagangan (Studi Kasus Perempuan Pedagang Pasar Johar Semarang). Project Report. Lembaga Penelitian Universitas Diponegoro.

Conwel, Robert, 2007, Gender and Power: Society, the Person, and Sexual Politics, Polity Press.

Eni Harmayanti, dkk. (2002). Wanita dalam Mata Rantai Perdagangan dan Industri Tempe. Yogyakarta: Laporan Penelitian PSW UGM.

Esther, Kuntjara, 2010,Gender, Bahasa Dan Kekuasaan, Gunung Mulia, Jakarta.

Ida Ayu, Komang, Arniati, 2012, Pandangan Gender Pada Smerti Dalam Perkembangan Modern, Paramitha, Surabaya.

Jalil, ST. Fatimah (2006), Peran Ganda Wanita Pedagang (Studi Kasus Pedagang Pakaian di Pasar sentral Kec. Wajo Kota Makassar, LPP UNHAS, Makassar.
Lubis, Rika Maya Sari (2009), Analisis FaktorFaktor Yang Mempengaruhi Pendapatan Pedagang Pakaian Wanita di Pasar Kota Tanjung Morawa, LPP USU Medan.

Mansour, Faqih, 2011, Analisis Gender dan Transformasi Sosial,INSIST Press .

Rahardja, Edy and Kusumawardhani, Arnie (2001) Profil Wanita Pedagang Tradisional: Tinjauan Kepribadian dan Prilaku Kewirausahaan (Studi Deskripsi Peran Wanita di Pedesaan Kabupaten Klaten, Jawa Tengah). LPP Universitas Diponegoro.

Sugiyanto; Keppi Sukesi; Indrati; Suhariningsih; Yayuk Yuliati (2003) Model Kelembagaan Perlindungan Sosial Perempuan Pedagang Kaki Lima di Jawa Timur. Pusat Penelitian dan Karya Ilmiah Universitas Muhammadiyah Sumatera Utara.

Yefni, Yoni (2008), Pola Kegiatan Wanita di Sektor Informal (Study Kasus Wanita Pedagang Sayur di Desa Batu Palano dan Padang Laweh Kecamatan Perwakilan Banuhampu, Sungai Puar, Kabupaten Agam).Master Thesis, Program Pasca Sarjana Universitas Andalas.

AhimAhimsa, H. 1988. Minawang; Hubungan Patron-Klien di Sulawesi Selatan. Yogyakarta: Gajah Mada University Press.

Hefni, Moh. 2009. Patron-Client Relationship Pada Masyarakat Madura. Dalam Jurnal Karsa. No. 01 hal 15-24. 